\title{
Regulation by Vitamin D Metabolites of Parathyroid Hormone Gene Transcription In Vivo in the Rat
}

\author{
Justin Silver," Tally Naveh-Many,* Hubert Mayer,‡ Hans Jurgen Schmelzer,‡ and Mordecai M. Popovtzer* \\ *Nephrology Services, Hadassah University Hospital, Jerusalem, Israel il-91120; and ¥Department of Genetics, \\ Gesellschaft für Biotechnologische Forschung, D-3300 Braunschweig, Federal Republic of Germany
}

\begin{abstract}
In vitro 1,25-dihydroxycholecalciferol $\left(1,25(\mathrm{OH})_{2} \mathrm{D}_{3}\right)$ decreased levels of preproparathyroid(preproPTH) hormone mRNA. We have now pursued these studies in vivo in the rat. Rats were administered vitamin $D$ metabolites i.p. and the levels of preproPTH mRNA were determined in excised parathyroidthyroid glands by blot hybridization. PreproPTH mRNA levels were $<4 \%$ of basal at $48 \mathrm{~h}$ after $100 \mathrm{pmol} 1,25(\mathrm{OH})_{2} \mathrm{D}_{3}$, with no increase in serum calcium. Gel blots showed that $1,25(\mathrm{OH})_{2} \mathrm{D}_{3}$ decreased preproPTH mRNA levels without any change in its size ( 833 basepair). Microdissected parathyroids after $1,25(\mathrm{OH})_{2} \mathrm{D}_{3}(100 \mathrm{pmol})$ showed mRNA levels for preproPTH were $40 \pm 8 \%$ of controls, but for $\beta$-actin were $100 \%$ of controls. The relative potencies of vitamin $D$ metabolites were: $1,25(\mathrm{OH})_{2} D_{3}>24,25(\mathrm{OH})_{2} D_{3}>25(\mathrm{OH}) D_{3}>$ vitamin $D_{3}$. In vitro nuclear transcription showed that $1,25(\mathrm{OH})_{2} \mathrm{D}_{3}$-treated (100 pmol) rats' PTH transcription was $10 \%$ of control, while $\beta$-actin was $100 \%$. These results show that $1,25(\mathrm{OH})_{2} \mathrm{D}_{3}$ regulates PTH gene transcription. PTH stimulates $1,25(\mathrm{OH})_{2} \mathrm{D}_{3}$ synthesis, which then inhibits PTH synthesis, thus completing an endocrinological feedback loop.
\end{abstract}

\section{Introduction}

Parathyroid hormone (PTH) ${ }^{1}$ and 1,25-dihydroxyvitamin D act together to regulate calcium homeostasis. PTH is trophic to 1,25dihydroxyvitamin $\mathrm{D}$ synthesis both directly and via its effect in lowering renal tubular phosphorus. Both hormones increase serum calcium concentration, which in turn decreases the secretion of PTH $(1,2)$.

There is also accumulating evidence that 1,25-dihydroxycholecalciferol $\left(1,25(\mathrm{OH})_{2} \mathrm{D}_{3}\right)$ itself has a direct effect on PTH synthesis and secretion. $1,25(\mathrm{OH})_{2} \mathrm{D}_{3}$ acts on target cells by mechanisms similar to those of the classic steroid hormones (3). Parathyroid cells have stereospecific, high affinity receptors for

The results of this study were reported in part at the Annual Meeting of the American Society for Nephrology, New Orleans, LA, 1985, and were published in abstract form (1986, Kidney Int, 29:172), and at the American Society for Bone and Mineral Research, Anaheim, CA, 1986.

Address reprint requests to Dr. Silver, Nephrology Services, Hadassah University Hospital, POB 12000, Jerusalem, Israel il-91120. 1986.

Received for publication 27 March 1986 and in revised form 17 July

1. Abbreviations used in this paper: $1,25(\mathrm{OH})_{2} \mathrm{D}_{3}, 1,25$-dihydroxycholecalciferol; PTH, parathyroid hormone.

J. Clin. Invest.

(c) The American Society for Clinical Investigation, Inc.

0021-9738/86/11/1296/06 \$1.00

Volume 78, November 1986, 1296-1301
$1,25(\mathrm{OH})_{2} \mathrm{D}_{3}(4,5)$ similar to the receptors found in the classic target sites for $1,25(\mathrm{OH})_{2} \mathrm{D}_{3}$, namely intestine and bone $(6,7)$. Moreover, after intravenous administration of $\left[{ }^{3} \mathrm{H}\right]-1,25(\mathrm{OH})_{2} \mathrm{D}_{3}$ to chicks and rats, there is marked accumulation of radioactivity in the parathyroid nuclei $(8,9)$. These data suggest that the parathyroid gland is a target organ for $1,25(\mathrm{OH})_{2} \mathrm{D}_{3}$.

Silver et al., using isolated bovine parathyroid cells in primary culture, showed in vitro that $1,25(\mathrm{OH})_{2} \mathrm{D}_{3}$ reduced preproPTH mRNA levels by $50 \%$ at $48 \mathrm{~h}$ (10). Cantley et al. showed that this reduced preproPTH mRNA level correlated with a similar reduction in PTH secretion by the cells at the corresponding times, with no effect of $1,25(\mathrm{OH})_{2} \mathrm{D}_{3}$ on PTH secretion at shorter time intervals (11). Thus in vitro $1,25(\mathrm{OH})_{2} \mathrm{D}_{3}$ has no effect on secretion of preformed hormone, but decreases the levels of preproPTH mRNA, probably by acting on DNA transcription. However, to establish that this in vitro effect of $1,25(\mathrm{OH})_{2} \mathrm{D}_{3}$ occurs under physiologically relevant conditions, it needed to be studied in vivo. In this report we have demonstrated in vivo in the rat that $1,25(\mathrm{OH})_{2} \mathrm{D}_{3}$ dramatically decreased parathyroid gland preproPTH mRNA over 3-48 $\mathrm{h}$ with no change in serum calcium, and that $1,25(\mathrm{OH})_{2} \mathrm{D}_{3}$ directly inhibits PTH gene transcription.

\section{Methods}

Animals. Male Hebrew University strain rats (150-180 g) were maintained on a normal diet and injected intraperitoneally with vitamin D metabolites dissolved in propylene glycol $(100 \mu \mathrm{l})$. At timed intervals the thyroids with attached parathyroids were excised under pentobarbital anesthesia, and blood samples taken. The excised tissue was immediately frozen in liquid nitrogen and stored at $-20^{\circ} \mathrm{C}$ until extraction. In some experiments parathyroids were microdissected from the thyroids in a petri dish positioned in a Lucite chamber perfused continuously with a cooling fluid to yield a constant temperature (12). The isolated parathyroids were then frozen as before.

Measurement of cellular mRNA levels. Total RNA was prepared from either thyroid-parathyroid or microdissected parathyroid tissue by homogenation in guanidium thiocyanate followed by deproteinization using guanidine hydrochloride and ethanol precipitation (13). Total RNA was redissolved in sterile water and quantitated at 260 and $280 \mathrm{~nm}$. The $A_{260} / A_{280}$ was always 1.9-2.0.

Dot blots of total tissue RNA extracts were prepared by formaldehyde denaturation followed by serial dilutions with $15 \times$ SSC ( $1 \times$ SSC, 0.15 $\mathrm{M} \mathrm{NaCl}$ and $0.01 \mathrm{M} \mathrm{Na}$ citrate). The diluted samples were spotted on a nitrocellulose filter $(0.45 \mu \mathrm{m}$; Schleicher \& Schuell, Keene, NH) soaked in $6 \times$ SSC using a manifold apparatus (Bethesda Research Laboratories, Gaithersburg, MD). In some experiments, RNA and markers were denatured and size-fractionated by electrophoresis on $1.5 \%$ agarose gels containing formaldehyde (14) and transferred to nitrocellulose filters by diffusion blotting. The size of PTH RNA was determined from the migration of the mammalian $28 \mathrm{~S}$ and $18 \mathrm{~S}$ ribosomal RNA markers. Nonspecific background hybridization was demonstrated by blotting total liver RNA at 10 and $20 \mu \mathrm{g}$. The filters were baked at $80^{\circ} \mathrm{C}$ for $120 \mathrm{~min}$ in a vacuum oven.

Hybridization. Rat preproPTH cDNA clone in plasmid PT43 was 
used (15). The gel-purified restriction fragments (Kpn I, Pst I) containing preproPTH cDNA ( 833 basepair [bp]) were labeled by nick-translation to a specific activity of $2-5 \times 10^{8} \mathrm{cpm} / \mu \mathrm{g}$ (16).

Hybridization was carried out over night at $42^{\circ} \mathrm{C}$, filters were exposed to $\mathrm{x}$-ray film for $24 \mathrm{~h}$, and the film was scanned with a densitometer.

Nuclear transcription and RNA isolation. Nuclei were purified for in vitro transcription as described (17). Freshly removed thyroid-parathyroid tissue was homogenized in $\sim 10 \mathrm{vol}$ of $0.3 \mathrm{M}$ sucrose in buffer A (60 $\mathrm{mM} \mathrm{KCl}, 15 \mathrm{mM} \mathrm{NaCl}, 0.15 \mathrm{mM}$ spermin, $0.5 \mathrm{mM}$ spermidine, 14 $\mathrm{mM} \beta$-mercaptoethanol, $0.5 \mathrm{mM}$ EGTA, $2 \mathrm{mM}$ EDTA, and $15 \mathrm{mM}$ Hepes [pH 7.5]). The homogenate was layered over a 10-ml cushion of $30 \%$ sucrose in buffer $A$, and centrifuged for $10 \mathrm{~min}$ at $2,500 \mathrm{rpm}$ in the HB4 rotor of a centrifuge (E. I. Du Pont de Nemours \& Co., Inc., Sorvall Instruments Div., Newton, CT) at $4^{\circ} \mathrm{C}$. The crude nuclei were resuspended in $2.5 \mathrm{ml} 2 \mathrm{M}$ sucrose in buffer $B$ (as A but $0.1 \mathrm{mM}$ EGTA and $0.1 \mathrm{mM}$ EDTA), layered over $2 \mathrm{M}$ sucrose in buffer $\mathrm{B}$, and sedimented at $36,000 \mathrm{rpm}$ in an SW 50 rotor (Beckman Instruments, Inc., Fullerton, CA) at $4^{\circ} \mathrm{C}$ for $1 \mathrm{~h}$. The nuclei were resuspended in storage buffer ( 20 $\mathrm{mM}$ Tris- $\mathrm{HCl}$ (pH 7.9), $75 \mathrm{mM} \mathrm{NaCl}, 0.5 \mathrm{mM}$ EDTA, $0.85 \mathrm{mM}$ dithiothreitol, $0.125 \mathrm{mM}$ phenylmethylsulfonyl fluoride $50 \%$ (vol/vol) glycerol), sedimented for $2 \mathrm{~min}$ in a cooled Eppendorf table centrifuge, and resuspended in the same buffer and stored at $-70^{\circ} \mathrm{C}$.

The in vitro transcription was carried out in a cocktail containing $100 \mathrm{mM}$ Tris-HCl (pH 7.9), $50 \mathrm{mM} \mathrm{NaCl}, 0.4 \mathrm{mM}$ EDTA, $0.1 \mathrm{mM}$ phenylmethylsulfonyl fluoride, $1.2 \mathrm{mM}$ dithiothreitol, $350 \mathrm{mM}$ $\left(\mathrm{NH}_{4}\right)_{2} \mathrm{SO}_{4}, 4 \mathrm{mM} \mathrm{MnCl}, 200 \mu \mathrm{Ci}$ of $\left[\alpha_{-}^{32} \mathrm{P}\right] \mathrm{UTP}(400 \mathrm{Ci} / \mathrm{mmol}), 1$ $\mathrm{mM}$ each of GTP, ATP, and CTP, $29 \%$ glycerol, $10 \mathrm{mM}$ creatinine phosphate, and $\sim 5 \times 10^{6} \mathrm{nuclei} / \mathrm{ml}$. Incubation was at $26^{\circ} \mathrm{C}$ for 10 min. Labeled RNA was extracted from the reaction mixture and hybridized to filters according to Groudine et al. (18). The level of RNA synthesis was the same for the control and $1,25(\mathrm{OH})_{2} \mathrm{D}_{3}$-treated parathyroid-thyroid nuclear preparations. $3 \times 10^{6} \mathrm{cpm}$ of purified RNA was obtained from each transcription of $10^{6}$ cells, and used for hybridization. Filters were prepared by spotting $5 \mu \mathrm{g}$ of linearized denatured plasmid DNAs on nitrocellulose.

\section{Results}

We first examined the tissue specificity of the preproPTH cDNA clone and showed that there was no hybridization with RNA extracts from rat liver, muscle brain, or thyroid. When rat parathyroid-thyroid tissue RNA was hybridized with the preproPTH cDNA clone, there was strong hybridization, which varied appropriately with serial dilution of each sample (Fig. 1, inset), and was quantitated by densitometric scanning. When $1,25(\mathrm{OH})_{2} \mathrm{D}_{3}$ at 50 or $100 \mathrm{pmol}$ was administered to rats at 0 $48 \mathrm{~h}$ before removing the parathyroid-thyroid tissue, relative hybridization with the preproPTH CDNA probe was markedly suppressed (Fig. 1). After 50 pmol $1,25(\mathrm{OH})_{2} \mathrm{D}_{3}$, levels of preproPTH mRNA were unchanged at $3 \mathrm{~h}$, but $<50 \%$ of basal at $6 \mathrm{~h}$, and $<20 \%$ at $24 \mathrm{~h}$. Rats given $100 \mathrm{pmol} 1,25(\mathrm{OH})_{2} \mathrm{D}_{3}$ had reduced preproPTH mRNA levels at $3 \mathrm{~h}$, which continued to decrease until $48 \mathrm{~h}$ when they were similar to rats given 50 pmol $1,25(\mathrm{OH})_{2} \mathrm{D}_{3}$ who had been given a second injection at $24 \mathrm{~h}$ (Fig. 1). Repeat experiments at various times (e.g., 3, 6, and $24 \mathrm{~h}$ ) showed virtually identical results. The serum calciums were not elevated at sacrifice in any of the groups of rats, e.g., $2.85 \pm 0.05 \mathrm{~mm}$ calcium $0-48 \mathrm{~h}$ after $100 \mathrm{pmol} 1,25(\mathrm{OH})_{2} \mathrm{D}_{3}$.

To determine whether $1,25(\mathrm{OH})_{2} \mathrm{D}_{3}$ influenced $\mathrm{mRNA}$ processing as well as mRNA levels, a Northern blot was performed. Total RNA was run on gel blots and then hybridized with ${ }^{32} \mathrm{P}$ labeled preproPTH cDNA. The preproPTH mRNA from control rats (Fig. 2, lanes 1 and 2$)$ and $1,25(\mathrm{OH})_{2} \mathrm{D}_{3}(100$ pmol)-treated rats (Fig. 2, lanes 3 and 4) was 833 bp, which corresponded to the size of the purified preproPTH cDNA fragment (Fig. 2, lane

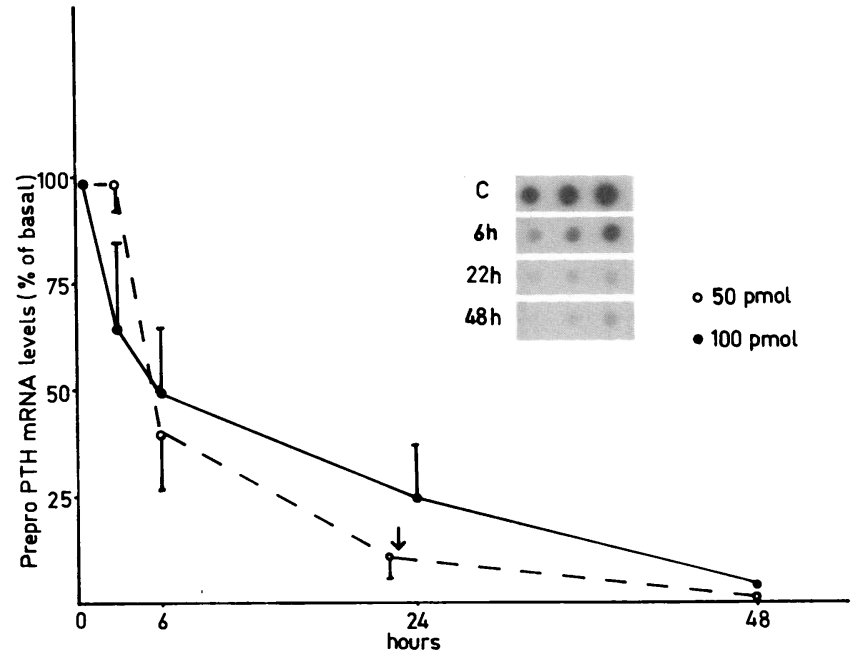

Figure 1. Time course of $1,25(\mathrm{OH})_{2} \mathrm{D}_{3}$ effect on preproPTH mRNA levels of rat parathyroid glands. The arrow indicates the second injection of $50 \mathrm{pmol} 1,25(\mathrm{OH})_{2} \mathrm{D}_{3}$. The inset shows representative autoradiographic spots for control (c) and $1,25(\mathrm{OH})_{2} \mathrm{D}_{3}$-treated rats $(100$ pmol) at 6, 22, and $48 \mathrm{~h}$. The three dots at each time are from increasing volumes of total RNA extracted from a single rat. Each point gives the mean \pm SE for four rats.

6). $1,25(\mathrm{OH})_{2} \mathrm{D}_{3}$ clearly decreased preproPTH mRNA in parathyroid tissue from a single rat (Fig. 2, lane 3), and parathyroid tissue combined from two rats (Fig. 2, lane 4) as compared with

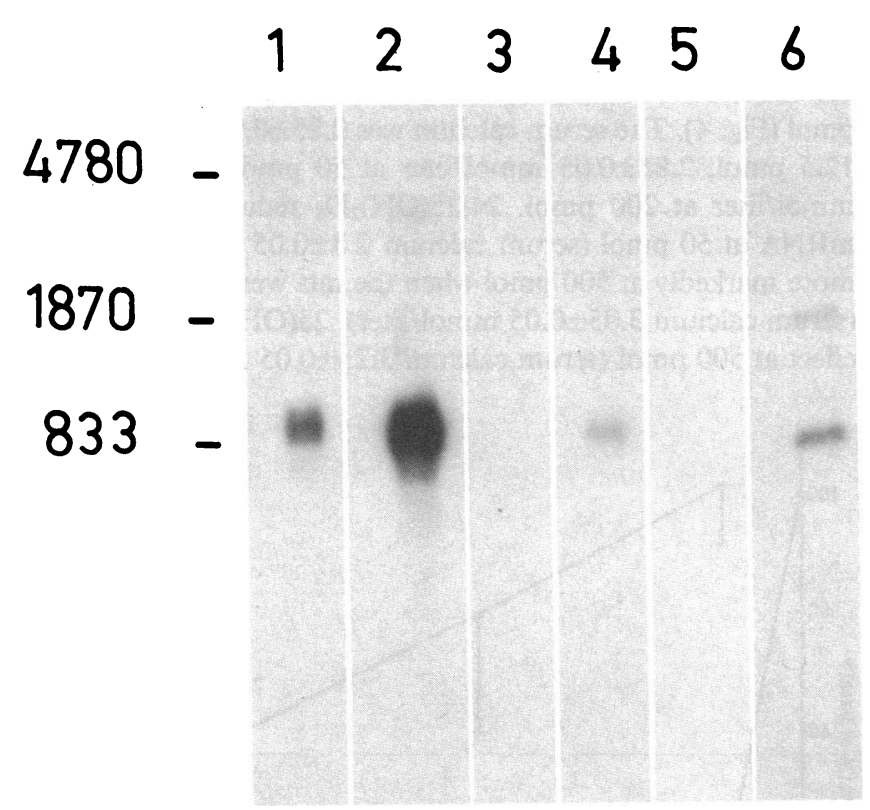

Figure 2. Gel blot analysis of total RNA from parathyroid-thyroid tissue after hybridization with ${ }^{32} \mathrm{P}$ nick-translated preproPTH cDNA. Lanes: 1, parathyroid-thyroid tissue RNA from one control rat; 2, parathyroid-thyroid tissue RNA from two control rats combined; 3, parathyroid-thyroid tissue RNA from one rat $24 \mathrm{~h}$ after $100 \mathrm{pmol}$ $1,25(\mathrm{OH})_{2} \mathrm{D}_{3}$ i.p.; 4 , the combined parathyroid-thyroid tissue RNA from two rats $24 \mathrm{~h}$ after $100 \mathrm{pmol} 1,25(\mathrm{OH})_{2} \mathrm{D}_{3}$ i.p.; 5, rat liver RNA; 6, purified preproPTH cDNA fragment. RNA size in nucleotide base pairs is shown for ribosomal $18 S$ and $28 S$ RNAs. 


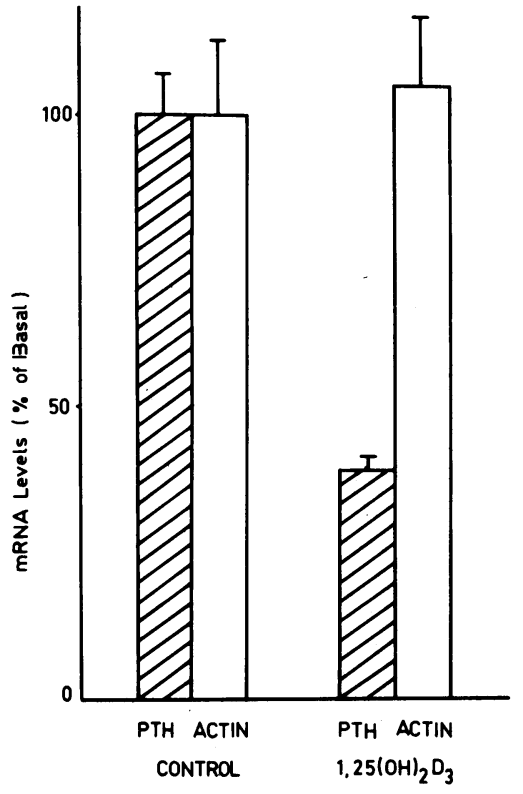

one control rat (Fig. 2, lane 1) or two control rats combined. There was no hybridization with rat liver (Fig. 2, lane 5).

To test the specificity of the effect of $1,25(\mathrm{OH})_{2} \mathrm{D}_{3}$ on preproPTH mRNA, the cellular concentration of mRNA for an unrelated protein, $\beta$-actin was studied. The level of preproPTH mRNA in microdissected parathyroids $24 \mathrm{~h}$ after an injection of 100 pmol $1,25(\mathrm{OH})_{2} \mathrm{D}_{3}$ was reduced by $60 \%$ as compared with control rats (Fig. 3). $1,25(\mathrm{OH})_{2} \mathrm{D}_{3}$ had no effect on the levels of $\beta$-actin mRNA (Fig. 3).

A vitamin $\mathrm{D}$ metabolite dose response study showed that the effect of $1,25(\mathrm{OH})_{2} \mathrm{D}_{3}$ in reducing preproPTH mRNA was evident even at 12.5 pmol with little change from 50 to 250 pmol (Fig. 4). The serum calcium was $2.85 \pm 0.05 \mathrm{mmol} / \mathrm{liter}$ at $12.5 \mathrm{pmol} ; 2.85 \pm 0.05 \mathrm{mmol} / \mathrm{liter}$ at $50 \mathrm{pmol}$; and $3.0 \pm 0.05$ $\mathrm{mmol} /$ liter at $200 \mathrm{pmol}$. $24,25(\mathrm{OH})_{2} \mathrm{D}_{3}$ reduced preproPTH mRNA at $50 \mathrm{pmol}$ (serum calcium $2.8 \pm 0.05 \mathrm{mmol} / \mathrm{liter}$ ) and more markedly at 500 pmol when the rats were hypercalcemic (serum calcium $3.05 \pm 0.05 \mathrm{mmol} / \mathrm{liter}$ ). $25(\mathrm{OH}) \mathrm{D}_{3}$ only had an effect at $500 \mathrm{pmol}$ (serum calcium $3.25 \pm 0.05 \mathrm{mmol} / \mathrm{liter}$ ) with no effect at $100 \mathrm{pmol}$ (serum calcium $2.8 \pm 0.05 \mathrm{mmol} / \mathrm{liter}$ ). Vitamin $D_{3}$ had no effect on preproPTH mRNA even at 500 pmol (serum calcium $3.0 \pm 0.05 \mathrm{mmol} / \mathrm{liter}$ ).

We investigated whether the $1,25(\mathrm{OH})_{2} \mathrm{D}_{3}$ regulation of preproPTH mRNA levels was mediated by an effect on PTH transcription by performing transcription run-off experiments. Nuclei were isolated from parathyroid-thyroid tissue of control and $1,25(\mathrm{OH})_{2} \mathrm{D}_{3}$-treated (100 pmol, $24 \mathrm{~h}$ earlier) rats and allowed to continue RNA synthesis in the presence of $\left[\alpha-{ }^{32} \mathrm{P}\right]$ UTP. Newly synthesized mRNA for preproPTH and $\beta$-actin were quantitated by hybridization to the immobilized cDNA. PreproPTH mRNA synthesis for $1,25(\mathrm{OH})_{2} \mathrm{D}_{3}$-treated rats was $10 \%$ of control, whereas $\beta$-actin mRNA for $1,25(\mathrm{OH})_{2} \mathrm{D}_{3}$-treated rats was $100 \%$ of control (Fig. 5). The control and $1,25(\mathrm{OH})_{2} \mathrm{D}_{3}$ treated nuclear preparations synthesized similar amounts of total mRNA as seen in the identical amounts of $\beta$-actin mRNA synthesized, as well as identical amounts of thyroglobulin mRNA (result not shown). pBR 322 was used as a negative control.

\section{Discussion}

The results of this in vivo study confirm the previous in vitro study that vitamin D metabolites regulate the levels of mRNA for preproPTH in the parathyroid gland (10). The present in vivo study demonstrated that after injection of physiological amounts of $1,25(\mathrm{OH})_{2} \mathrm{D}_{3}$ to normal rats that did not raise serum calcium, there was a dramatic reduction in preproPTH mRNA levels. The effect of $1,25(\mathrm{OH})_{2} \mathrm{D}_{3}$ was clearly evident at $3 \mathrm{~h}$ after injection and was even more marked at later time intervals (Fig. 1).

The level of preproPTH mRNA was $<1 \%$ of basal $48 \mathrm{~h}$ after 100 pmol $1,25(\mathrm{OH})_{2} \mathrm{D}_{3}$, demonstrating a remarkably potent negative control. Vitamin $\mathrm{D}_{3}$ itself did not reduce preproPTH mRNA levels at all, whereas $25(\mathrm{OH}) \mathrm{D}_{3}$ was only minimally effective (20\% reduction) at pharmacological doses $(500 \mathrm{pmol})$ (Fig. 4). $24,25(\mathrm{OH})_{2} \mathrm{D}_{3}$ was also much less potent than $1,25(\mathrm{OH})_{2} \mathrm{D}_{3}$, similar to their dose-response curves in vitro. It is possible that some of the $24,25(\mathrm{OH})_{2} \mathrm{D}_{3}$ effect in vivo was due to its metabolism to $1,24,25(\mathrm{OH})_{3} \mathrm{D}_{3} .25(\mathrm{OH}) \mathrm{D}_{3}$ at $500 \mathrm{pmol}$ only had a modest effect on preproPTH mRNA despite causing marked hypercalcemia (serum calcium 3.25 $\pm 0.05 \mathrm{mmol} / \mathrm{liter}$ ),

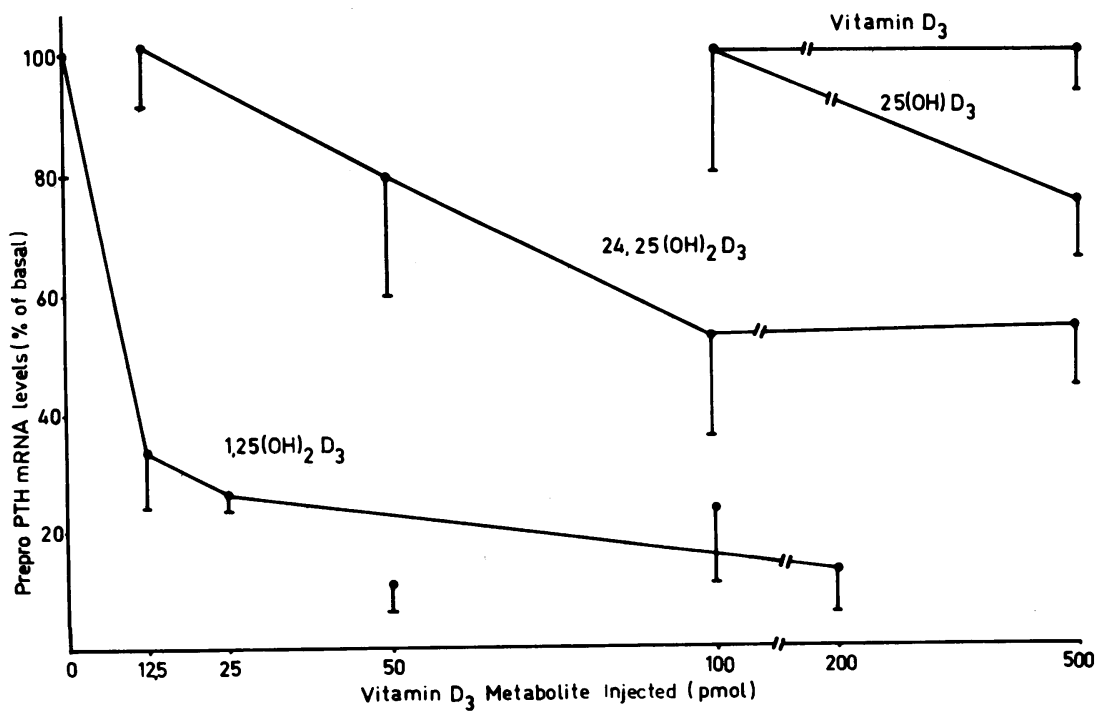

Figure 4. Vitamin $D_{3}$ metabolite dose response effect on parathyroid gland preproPTH mRNA $24 \mathrm{~h}$ after intraperitoneal injections. The results represent mean \pm SEM for four rats. 
Figure 5. Nuclear transcription run-offs for PTH and $\beta$-actin of control and $1,25(\mathrm{OH})_{2} \mathrm{D}_{3}$-treated rats. 18 control rats and 18 rats treated with $1,25(\mathrm{OH})_{2} \mathrm{D}_{3} 100$ pmol i.p. $24 \mathrm{~h}$ earlier were used. The parathyroid-thyroid tissue from the 18 control rats was pooled and that from the $1,25(\mathrm{OH})_{2} \mathrm{D}_{3^{-}}$ treated rats was pooled, and nuclei isolated from each of the two preparations. Newly synthesized mRNA sequences were quantitated by hybridization to immobilized cDNA for preproPTH (in duplicate) and $\beta$-actin. pBR 322 plasmid was a nonspecific control (see Methods).

(100 pmol)

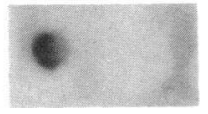

and vitamin $D_{3}$ at 500 pmol caused hypercalcemia (serum calcium $3.0 \pm 0.05 \mathrm{mmol} /$ liter) with no effect on preproPTH mRNA levels.

A Northern blot showed that the preproPTH mRNA was $833 \mathrm{bp}$ and that the preproPTH mRNA from both control and $1,25(\mathrm{OH})_{2} \mathrm{D}_{3}$-treated rats had the same electrophoretic mobility with no larger mRNA fragments after $1,25(\mathrm{OH})_{2} \mathrm{D}_{3}$ (Fig. 2). The effect of $1,25(\mathrm{OH})_{2} \mathrm{D}_{3}$ was therefore on PTH gene transcription or preproPTH mRNA half-life and not on mRNA processing. The decrease in preproPTH mRNA levels caused by $1,25(\mathrm{OH})_{2} \mathrm{D}_{3}$ was clearly demonstrated in the Northern blot.

The specificity of the $1,25(\mathrm{OH})_{2} \mathrm{D}_{3}$ effect on preproPTH mRNA was studied by comparing the levels of mRNA for preproPTH and $\beta$-actin in the same parathyroid gland RNA extracts. While microdissected rat parathyroids' mRNA for preproPTH was reduced $60 \%$ by a single $1,25(\mathrm{OH})_{2} \mathrm{D}_{3}$ injection $(100 \mathrm{pmol})$, there was no change in $\beta$-actin mRNA. These results confirm the specificity of the $1,25(\mathrm{OH})_{2} \mathrm{D}_{3}$ effect that had been shown in vitro.

To determine whether the $1,25(\mathrm{OH})_{2} \mathrm{D}_{3}$ regulation of preproPTH mRNA levels was mediated transcriptionally, we performed nuclear transcription run-off experiments. In this system RNA synthesis consists of elongation and completion of previously initiated RNA molecules. Thus, the labeling of nascent RNA in vitro accurately reflects the RNA initiation that occurred in vivo. There was a dramatic reduction in PTH transcription in $1,25(\mathrm{OH})_{2} \mathrm{D}_{3}$-treated rats to $10 \%$ of control rats (Fig. 5 ), whereas $\beta$-actin transcription in the same $1,25(\mathrm{OH})_{2} \mathrm{D}_{3}$ treated rats was $100 \%$ of control. pBR322 plasmid did not hybridize. This confirms the specificity of the PTH and $\beta$-actin hybridization.

These in vivo results now establish that vitamin $D$ metabolites regulate preproPTH mRNA levels through its effect on PTH gene transcription, and that $1,25(\mathrm{OH})_{2} \mathrm{D}_{3}$ is a major factor in the regulation of the PTH gene. There are cytoplasmic receptors for $1,25(\mathrm{OH})_{2} \mathrm{D}_{3}$ in parathyroid cells $(4,5)$ and $1,25(\mathrm{OH})_{2} \mathrm{D}_{3}$ accumulates in parathyroid nuclei $(6,7)$. The parathyroid cell is therefore an important target organ for $1,25(\mathrm{OH})_{2} \mathrm{D}_{3}$. It is postulated that steroid hormones enter cells by facilitated diffusion and bind to the specific receptor protein, initiating an allosteric alteration of the complex, which then binds to chromosomal DNA with high affinity (19). The modulation of specific gene transcription is dependent upon sequences in their $5^{\prime}$ flanking regions that preferentially bind receptors (19). The specific binding sites for the $1,25(\mathrm{OH})_{2} \mathrm{D}_{3}$ receptor complex that regulates preproPTH gene transcription is currently being studied.

There is no parathyroid cell line but the rat pituitary cell line $\left(\mathrm{GH}_{4} \mathrm{C}_{1}\right)$ has a $1,25(\mathrm{OH})_{2} \mathrm{D}_{3}$ cytosol-binding protein and responds to added $1,25(\mathrm{OH})_{2} \mathrm{D}_{3}$ by a marked increase in prolactin mRNA and prolactin synthesis, with no increase in growth hormone mRNA or synthesis (20). Extracellular calcium only increased prolactin mRNA when $1,25(\mathrm{OH})_{2} \mathrm{D}_{3}$ was present, and had no effect when no $1,25(\mathrm{OH})_{2} \mathrm{D}_{3}$ was added, demonstrating an interesting interaction between cellular $1,25(\mathrm{OH})_{2} \mathrm{D}_{3}$ and calcium. Moreover, preliminary evidence from Kronenberg's laboratory using the same cell line transfected with the human PTH gene showed that added $1,25(\mathrm{OH})_{2} \mathrm{D}_{3}\left(10^{-7} \mathrm{M}\right)$ significantly reduced PTH mRNA levels (21). These data all indicate that the $1,25(\mathrm{OH})_{2} \mathrm{D}_{3}$ effect on PTH is on PTH gene transcription.

The concentration of serum-ionized calcium is the major factor that controls the secretion of PTH; low calcium stimulates and high calcium suppresses PTH secretion $(1,2) .1,25(\mathrm{OH})_{2} \mathrm{D}_{3}$ increases intestinal calcium absorption and consequently may raise the serum calcium level. It is therefore important to consider whether the effect of $1,25(\mathrm{OH})_{2} \mathrm{D}_{3}$ on preproPTH mRNA is mediated by calcium. Heinrich et al. showed in vitro that high calcium ( $5 \mathrm{mM}$ ) did not change preproPTH mRNA levels of

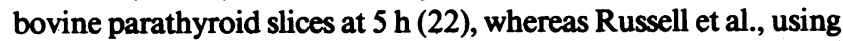
isolated bovine parathyroid cells, showed that high calcium $(2.5$ $\mathrm{mM}$ ) over longer periods ( $24 \mathrm{~h}$ ) decreased preproPTH mRNA levels (23). The effect of $1,25(\mathrm{OH})_{2} \mathrm{D}_{3}$ in markedly decreasing preproPTH mRNA in isolated bovine parathyroid cells was certainly not a function of extracellular fluid calcium, which was maintained at $1.25 \mathrm{mM}$ (10). In the present studies there was no increase in serum calcium when $1,25(\mathrm{OH})_{2} \mathrm{D}_{3}$ was administered to the rats at $12.5-200$ pmol for time periods from 3 to $48 \mathrm{~h}$. Moreover, the lower doses represent physiological doses of $1,25(\mathrm{OH})_{2} \mathrm{D}_{3}$ that would hardly be expected to raise serum calcium. Pharmacological doses of vitamin $\mathrm{D}_{3}$ caused-hypercalcemia with no effect on preproPTH mRNA levels, and of $25(\mathrm{OH}) \mathrm{D}_{3}$ caused hypercalcemia with minimal effects on preproPTH mRNA levels, both suggesting that $1,25(\mathrm{OH})_{2} \mathrm{D}_{3}$ and not calcium regulates preproPTH mRNA levels. However, as yet, we have not studied the effects of calcium on PTH nuclear transcription. The effect of alterations in vivo of serum calcium on preproPTH mRNA is being studied separately. $1,25(\mathrm{OH})_{2} \mathrm{D}_{3}$ has been shown to affect the lipid composition of cell membranes and thereby increase transcellular calcium transport (24). It is therefore possible some of the effect of $1,25(\mathrm{OH})_{2} \mathrm{D}_{3}$ on preproPTH mRNA may be due to an ionophore effect of $1,25(\mathrm{OH})_{2} \mathrm{D}_{3}$ rather than its classic mode of action on the cell genome. We did not study possible transient post-prandial changes in serum calcium. Whatever the mechanism of the $1,25(\mathrm{OH})_{2} \mathrm{D}_{3}$ effect on parathyroid hormone gene transcription or preproPTH mRNA half-life, it is an effect of $1,25(\mathrm{OH})_{2} \mathrm{D}_{3}$ and not of alteration in serum calcium.

A $1,25(\mathrm{OH})_{2} \mathrm{D}_{3}$-induced reduction in PTH transcription 
would be translated into lower levels of secreted PTH. This question has been widely studied both in vitro and in vivo with conflicting results. In vitro, in the short term incubations $(0.5-$ $4 \mathrm{~h}$ ) most studies showed that $1,25(\mathrm{OH})_{2} \mathrm{D}_{3}$ had no effect on PTH secretion $(11,25)$, but for longer incubations (e.g., 24$48 \mathrm{~h}$ ) there is a dose-dependent reduction in PTH secretion (11, 26) that closely paralleled levels of preproPTH mRNA (11). The $1,25(\mathrm{OH})_{2} \mathrm{D}_{3}$ effect on PTH secretion might therefore be a consequence of the decreased preproPTH mRNA and subsequently decreased PTH synthesis. Chertow et al. (27) found in vivo decreased serum PTH in rats given $1,25(\mathrm{OH})_{2} \mathrm{D}_{3}$, results not confirmed in the rat (28) or in humans (29). In situations of parathyroid hyperplasia (e.g., chronic renal failure) there is an increased set-point for calcium suppression of PTH release (30). Calcium set-point is defined as the calcium concentration halfmaximally suppressing PTH release. Slatopolsky et al. showed that in chronic renal failure patients on chronic intermittent hemodialysis that intravenous $1,25(\mathrm{OH})_{2} \mathrm{D}_{3}$ given after dialyses markedly suppressed (70\%) serum PTH levels, whereas raising the serum calcium by oral calcium only decreased iPTH by $25 \%$ (31). Therefore, even where there is an increased parathyroid mass with altered set-point, as in chronic renal failure, $1,25(\mathrm{OH})_{2} \mathrm{D}_{3}$ is an important factor in controlling serum PTH levels. In acute renal failure, where there is no parathyroid hyperplasia, Madson et al. showed that intravenous $1,25(\mathrm{OH})_{2} \mathrm{D}_{3}$ significantly reduced serum PTH without any change in serum calcium (32). These human studies used intravenous 1,25$(\mathrm{OH})_{2} \mathrm{D}_{3}$, which would provide a greater delivery of the sterol to target organs such as the parathyroid, than oral $1,25(\mathrm{OH})_{2} \mathrm{D}_{3}$.

When $1,25(\mathrm{OH})_{2} \mathrm{D}_{3}$ is given orally it markedly increases calcium absorption and is itself partially metabolized in the intestine (3). The $1,25(\mathrm{OH})_{2} \mathrm{D}_{3}$ given intraperitoneally to the rats in the present study is comparable to intravenous $1,25(\mathrm{OH})_{2} \mathrm{D}_{3}$, and would be handled like $1,25(\mathrm{OH})_{2} \mathrm{D}_{3}$ produced endogenously.

$1,25(\mathrm{OH})_{2} \mathrm{D}_{3}$ therefore appears to be the major factor controlling PTH gene transcription, as shown by in vitro studies (10) and the present in vivo studies, and this is manifested by its effect in vivo on serum PTH levels. Calcium is the major determinant of parathyroid activity by its control of PTH secretion and catabolism. In addition the parathyroid gland responds to chronically low levels of extracellular calcium (e.g., days or weeks) by hypertrophy and proliferation of parathyroid cells with a tremendous increase in total PTH production $(1,2)$. Whereas calcium controls parathyroid cell replication and PTH secretion, the control of parathyroid transcription and hence PTH production by the individual parathyroid cells may be determined by $1,25(\mathrm{OH})_{2} \mathrm{D}_{3}$, as the present studies show. Whether calcium has any role in the regulation of the parathyroid gene is currently being studied.

In summary, PTH increases renal $1,25(\mathrm{OH})_{2} \mathrm{D}_{3}$ synthesis and both hormones then act to raise serum calcium, which in turn decreases PTH secretion. 1,25(OH $)_{2} \mathrm{D}_{3}$ itself decreases PTH synthesis and hence serum PTH levels thus completing the endocrinological loop.

\section{Acknowledgments}

We express our appreciation for the helpful discussions of Dr. H. Cedar, and to Dr. D. Jaffe for providing the $\beta$-actin, the vitamin D metabolites supplied by Drs. Meier and Solms (Hoffmann-La Roche, Inc., Basle, Switzerland), and the technical assistance of Ms. M. Ofner.
This work was supported by the Fund for Basic Research Administered by the Israel Academy of Sciences and Humanities, and the Israel Cancer Association. During the period of this research, Dr. Tally NavehMany was supported by a fellowship from the Israel Cancer Research Fund.

\section{References}

1. Parfitt, A. M., and M. Kleerekopey. 1980. The divalent ion homeostatic system: physiology and metabolism of calcium, phosphorus, magnesium and bone. In Clinical Disorders of Fluid and Electrolyte Metabolism. 3rd ed. M. H. Maxwell and C. R. Kleeman, editors. MaGraw Hill Book Co., Inc., New York, 269-398.

2. Habener, J. F., M. Rosenblatt, and J. T. Potts, Jr. 1984. Parathyroid hormone: biochemical aspects of biosynthesis, secretion, action and metabolism. Physiol. Rev. 64:985-1053.

3. Fraser, D. R. 1980. Regulation of the metabolism of vitamin D. Physiol. Rev. 60:551-613.

4. Hughes, M. R., and M. R. Maussler. 1978. 1,25-dihydroxycholecalciferol receptors in parathyroid glands. J. Biol. Chem. 253:10651069.

5. Wecksler, W. R., F. P. Ross, R. S. Mason, S. Posen, and A. W. Norman. 1980. Biochemical properties of the 1,25-dihydroxy-vitamin D cytoplasmic receptors from human and chick para-thyroid glands. Arch. Biochem. Biophys. 201:95-102.

6. Tsai, H. C., and A. W. Norman. 1980. Studies on calciferol metabolism. VIII. Evidence for a cytoplasmic receptor for 1,25-dihydroxyvitamin $\mathrm{D}_{3}$ in the intestinal mucosa. J. Biol. Chem. 248:5967-5975.

7. Chen, T. L., M. A. Hirst, and D. Feldman. 1979. A receptor-like binding macromolecule for 1,25-dihydroxycholecalciferol in cultured mouse bone cells. J. Biol. Chem. 254:7491-7494.

8. Wecksler, W. R., H. L. Henry, and A. W. Norman. 1977. Studies on the mode of action of calciferol. Subcellular localization of 1,25dihydroxycholecalciferol in chicken parathyroid glands. Arch. Biochem. Biophys. 183:168-173.

9. Stumpf, W. E., M. Sar, F. A. Reid, Y. Tanaka, and H. F. De Luca. 1979. Target cells for $1,25(\mathrm{OH})_{2} \mathrm{D}_{3}$ in intestinal tract, stomach, kidney, skin, pituitary and parathyroid. Science (Wash. DC). 206:1188-1190.

10. Silver, J., J. Russell, D. Lettieri, and L. M. Sherwood. 1985. Regulation by vitamin D metabolites of messenger ribonucleic acid for prepropara thyroid hormone in isolated bovine parathyroid cells. Proc. Natl. Acad. Sci. USA. 82:4270-4273.

11. Cantley, L. K., J. Russell, D. Lettieri, and L. M. Sherwood. 1985. 1,25-dihydroxyvitamin $D_{3}$ suppresses parathyroid hormone secretion from bovine parathryoid cells in tissue culture. Endocrinology. 117:21142119.

12. Scherzer, P., H. Wald, and J. W. Czaczkes. 1985. Na-K-ATPase in isolated rabbit tubules after unilateral nephrectomy and $\mathrm{Na}^{+}$loading. Am. J. Physiol. 248:F565-F573.

13. Chirgwin, J. M., A. E. Przybyla, R. J. MacDonald, and W. J. Rutter. 1979. Isolation of biologically active ribonucleic acid from sources enriched in ribonuclease. Biochemistry. 18:5294-5299.

14. Lehrach, H., D. Diamond, J. M. Wozney, and H. Boedtker. 1977. RNA molecular weight determinations by gel electrophoresis under denaturing conditions: a critical reexamination. Biochemistry. 16:47434751.

15. Schmelzer, H.-J., G. Gross, and H. Mayer. 1984. Nucleotide sequence of cloned cDNA encoding rat preproparathyroid hormone. ICSU Short Reports. Advances in Gene Technology. Human Genetic Disorders. Proceedings of the 16th Miami Winter Symposium. F. Ahmad, S. Black, J. Schultz, W. A. Scott, and W. J. Whelan, editors. Vol. 1, 234235.

16. Rigby, P. J. W., M. Dieckmann, C. Rhodes, and P. Berg. 1977. Labeling deoxyribonucleic acid to high specific activity in vitro by nick translation with DNA polymerase I. J. Mol. Biol. 113:237-251.

17. Schibler, U., O. Hagenbuchle, P. K. Wellauer, and A. C. Pittet. 1983. Two promoters of different strengths control the transcription of 
the mouse alpha-amylase gene amy- $1^{2}$ in the parotid gland and the liver. Cell. 33:501-508.

18. Groudine, M., M. Peretz, and H. Weintraub. 1981. Transcriptional regulation of hemoglobin switching in chicken embryos. Mol. Cell. Biol. 1:281-288.

19. O'Malley, B. W. 1984. Steroid hormone action in eucaryotic cells. J. Clin. Invest. 74:307-312.

20. Wark, J. D., and A. H. Tashjian, Jr. 1983. Regulation of prolactin mRNA by 1,25 -dihydroxyvitamin $\mathrm{D}_{3}$ in $\mathrm{GH}_{4} \mathrm{C}_{1}$ cells. J. Biol. Chem. 258:12118-12121.

21. Igarashi, T., T. Okazaki, R. D. Gaz, J. T. Potts, Jr., and H. M. Kronenberg. 1985. Regulation of parathyroid hormone gene expression in transfected rat pituitary cells. American Society for Endocrinology Meeting, Washington D. C., June 19-22.

22. Heinrich, G., H. M. Kronenberg, J. T. Potts, Jr., and J. R. Habener. 1983. Parathyroid hormone messenger ribonucleic acid. Effects of calcium on cellular regulation in vitro. Endocrinology. 112:449-458.

23. Russell, J. R., D. Lettieri, and L. M. Sherwood. 1983. Direct regulation by calcium of cytoplasmic mRNA coding for pre-proparathyroid hormone in isolated bovine parathyroid cells. J. Clin. Invest. 72: 1851-1855.

24. Rasmussen, H., T. Matsumoto, O. Fontaine, and D. G. P. Goodman. 1982. Role of changes in membrane lipid structure in the action of 1,25-dihydroxyvitamin $D_{3}$. Fed. Proc. 41:72-77.

25. Golden, P., A. Greenwalt, K. Martin, E. Bellorin-Font, R. Mazey, S. Klahr, and E. Slatopolsky. 1980. Lack of a direct effect of 1,25-di- hydroxycholecalciferol on parathyroid hormone secretion by normal bovine parathyroid glands. Endocrinology. 107:602-607.

26. Au, W. Y. W. 1984. Inhibition by 1,25 dihydroxycholecalciferol of hormonal secretion of rat parathyroid gland in organ culture. Calcif. Tissue Int. 36:384-391.

27. Chertow, B. S., D. J. Baylink, J. E. Wergedahl, M. H. H. Su, and A. W. Norman. 1975. Decrease in serum immunoreactive parathyroid hormone in rats and in parathyroid hormone secretion in vitro by 1,25 dihydroxycholecalciferol. J. Clin. Invest. 56:668-675.

28. Tanaka, Y., H. F. De Luca, J. G. Ghazarlan, G. K. Hargis, and G. A. Williams. 1979. Effect of vitamin D and its metabolites on serum parathyroid hormone in the rat. Mineral Electrolyte Metab. 2:20-25.

29. Llach, F., J. W. Coburn, A. S. Brickman, K. Kurokawa, A. W. Worman, J. M. Canterbury, and E. Reiss. 1977. Acute effects of 1,25dihydroxyvitamin $\mathrm{D}_{3}$ in normal man: effect on calcium and parathyroid hormone. J. Clin. Endocrinol. \& Metab. 44:1034-1040.

30. Brown, E. M. 1983. Four-parameter model of the relationship between parathyroid hormone release and extracellular calcium concentration in normal and abnormal parathyroid tissue. J. Clin. Endocrinol. \& Metab. 56:572-581.

31. Slatopolsky, E., C. Weerts, J. Thielan, R. Horst, H. Harter, and K. J. Martin. 1984. Marked suppression of secondary hyperparathyroidism by intravenous administration of 1,25-dihydroxycholecalciferol in uremic patients. J. Clin. Invest. 74:2136-2143.

32. Madsen, S., K. Olgaard, and J. Ladefoged. 1981. Suppressive effect of 1,25-dihydroxyvitamin $\mathrm{D}_{3}$ on circulating parathyroid hormone in acute renal failure. J. Clin. Endocrinol. \& Metab. 53:823-827. 